\title{
The Levels of Motivation among Employees in a Selected Public Service Department
}

\section{Wiza Munyeka}

Department of Business Management, University of Limpopo (Turf loop Campus), Private Bag 1106. Sovenga, 0727. South Africa Email: masterwiza2000@yahoo.com

\author{
Doi:10.5901/mjss.2014.v5n20p960
}

\begin{abstract}
This research examined the levels of motivation among employees in a selected public service department in the Limpopo Province. The study used a non-probability sampling procedure to select the sample; specifically the convenience sampling technique was used whereby 30 respondents were selected. A closed ended questionnaire was used in the study. Descriptive statistics were used to analyse data. Results showed that the levels of motivation among employees in the selected public service department were very low.
\end{abstract}

Keywords: Motivation; Direction; Intensity; Job Satisfaction; Persistence; Pubic Service Department

\section{Introduction}

One of the most pressing problems facing organisations today is how to motivate employees to work more productively, and to increase their feelings of satisfaction, involvement and commitment. The concept of motivation and job satisfaction and involvement are interrelated - satisfaction and involvement can result from the fulfillment of motivations, and new sources of satisfaction and involvement can generate other motivations (Schultz \& Schultz, 1990:317).

According to Robbins, Odendaal \& Roodt (2003:130), motivation is the result of the interaction of the individual and situation. Individuals differ in their basic motivational drive. It is the process that accounts for an individual's intensity, direction and persistence of effort towards attaining a goal to motivating people one should keep them inspired and focused on reinventing themselves. People are motivated by many different things but most importantly, we are motivated by a sense of excitement (Robbins et al, 2003:150).

\section{Problem Statement}

In the current competitive business environment, organisations are facing a lot of challenges and among these issues, getting the right employees and retaining them is one of the most important ones. In addition, today, the benefit of human resource is measured to be one of the most important advantages of any organization; and in order to acquire the results with the highest efficiency and effectiveness from human resource, motivation of employee is very essential. The likelihood of potential and experienced staff moving from existing public service departments to private organisations due to the attractive packages offered by private organisations is a source of worry because they need to be replaced at a higher cost to fill the gap. Thus, the current study carries an investigation into the levels of motivation among the employees in a selected public service department.

\section{Objectives of the Study}

- The objectives of this study is to investigate factors that negatively affect the levels of motivation of employees in a selected public service department in the Limpopo Province and to identify measures that can be taken in order to motivate them.

- To identify factors that positively affects the levels of motivation in a selected public service department in the Limpopo Province.

- To determine strategies that management uses to rectify the problem of the levels of motivation. 


\section{Research Questions}

- What are the levels of motivation of public service employees in a selected public service department in the Limpopo Province?

- What are the factors that affect the levels of employees' level of motivation in a selected public service department in the Limpopo Province?

- What are the factors that positively affect the employees' level of motivation in a selected public service department in the Limpopo Province?

- What strategies does the management use in order to rectify the problem of employees' levels of motivation?

\section{Literature Review: Motivation}

Motivation is the driving force within individuals that impels them to action. It is produced by a state of a tension which exists as a result of an unfulfilled need. Individuals strive both consciously and unconsciously that reduce this tension through behaviour that they anticipate will fulfill their needs and thus relieve themselves of the stress they feel (Shiffman \& Kanuk, 2006:63).

According to Munchinsky (2003:373), motivation can be conceptualized along three dimensions; direction, intensity and persistence. He argued that in an employment context, each dimension is highly relevant to the organisation as well as to the individual. Direction pertains to those activities to which one directs his energy. Organisations want employees who will direct themselves to their work responsibilities; on the other hand, employees want jobs that will inspire their motivation and commitments. Intensity pertains to the amount of motivation that is expanded in pursuit of an activity.

Munchinsky (2003:373 furthermore stated that organisations want employees who will exhibit high levels of energy. Those are often referred to as 'self-motivated individuals', this implying that they bring a level of energy to the job and do not require organisational inducement to work hard. Likewise, many employees hope to find jobs that sufficiently appealing to invite large commitments of energy. Persistence pertains sustaining of energy overtime and is concerned with how long the energy will be expended.

According to Newstrom \& Davis (2003:103), "All behaviour is motivated." Getting out of bed when the alarm clock rings, brushing your teeth, shaving, selecting the day's necktie, ordering rolls and coffee or ham and eggs from the menu card, picking up the newspaper to read the news, these daily activities are all casually determined. It is commonly known that our conduct is determined by desires, purposes, fears and similar factors. Even the unconscious motive derived from early childhood influences determine the present behaviour.

Motivation and inspiration energise people, not by pushing them in the right direction as control mechanisms do, but by satisfying basic human needs for achievement, a sense of belonging, recognition of self-esteem, a feeling of control over one's life and the ability to live up one's ideals. Such feelings touch us deeply and elicit a powerful response. Good leaders motivate people in a variety of ways. Firstly, the articulate the organisation's vision in a manner that stresses the values of the audience they are addressing. This makes the work important to those individuals. Leaders also regularly improve people in deciding how to achieve the organisation's vision. Another important motivational technique is to support employee efforts to realize the vision by providing coaching, feedback and role modeling, thereby helping people grow professionally and enhancing their self-esteem. Finally, good leaders recognize and reward success, which not only gives people a sense of accomplishment but also makes them feel like they belong to an organisation that cares about them. When this is done, the work itself becomes intrinsically motivating (Van der Merwe \& Bisschoff, 2001:27).

\subsection{Motivational theories}

In the 1930s, motivation was considered to be an important aspect of human behaviour, but no scientifically-based theory could explain it (Luthans, 1989). Maslow, however, postulated motivation in terms of a need hierarchy theory (Oosthuizen, 2001; Robbins, 1998; Swanepoel, Erasmus, Van Wyk \& Schenk 1998; 2003). Motivation theories are divided into content theories, which are those theories that explain the "what" of motivation and process theories, which are those theories that explain the "how" of motivation (Nel, Gerber, Van Dyk, Haasbroek, Schultz, Sono, \& Werner, 2003). 


\subsubsection{Maslow's hierarchy of needs}

Abraham Maslow divided human needs into five progressive levels, from physiological, safety, social, ego to selfactualization needs. The premise of this theory is that managers can use unsatisfied needs to motivate employees. Consistent emphasis on lower level needs does not produce desirable results as these needs are mostly satisfied for people in modern society. The higher level needs, on the other hand, provide limitless opportunities for satisfaction. They also provide the opportunity for employees to take control of their own work environment (Nel et.al, 2003). These needs are described as follows: Physiological needs, Safety and security needs, Belonging, love and social needs, Status, Selfesteem needs, and Self-actualization needs.

According to the theory, the needs at lower levels have to be fulfilled to some extent before those at the next higher level can be satisfied (Schulze \& Steyn, 2003; Steyn, 2002). The lower four needs are called deficiency needs because they motivate people to meet them and until they are met, people find it difficult to respond to higher order or so-called growth needs (Greenberg \& Baron, 2003; Newstrom \& Davis, 1989; Owens, 1995, Everand \& Morris, 1996, Wagner \& Hollenbeck, 1998, McKenna, 2000 all cited in Steyn, 2002). The differentiation between the two orders was made on the premise that higher-order needs are satisfied internally (within the person), whereas lower-order needs (such as wages, bonus, or tenure) are predominantly satisfied externally Swanepoel et. al (1998).

\subsubsection{McClelland's achievement motivation theory}

According to Nel et.al (2003), McClelland identified three needs, namely the need for affiliation, power and achievement, she also stated that higher achievers have unique skills which drive their need to perform. Mullins (1996); Robbins (1998) and Sherman, Bohlander and Snell (1996), added that McClelland proposes that there are three basic needs that are operative in the workplace, that are:

- $\quad$ The need for achievement, which is the desire to exceed some standard of behaviour; the need to excel; the need to be successful.

- The need for power, which is the need to make others behave in a way in which they would not otherwise have behaved, the need to control others, to be influential.

- The need for affiliation, which is the need for warm and close interpersonal relationships, to be liked and accepted by others.

Swanepoel et. al (2003), states that if the above needs constitute the totality of needs, it remains for the manager to determine his/her subordinates' dominant need and to offer opportunities whereby the individual's needs and the organisation's goals can simultaneously be met. Robbins (1998), outlined that research undertaken by McClelland and other researchers, has revealed that a person with a high need for achievement prefers jobs with moderate risk, performance feedback and responsibility for performance. According to Swanepoel et. al (1998:2003), under these conditions, high achievers will be strongly motivated.

\subsubsection{Herzberg's two-factor motivation theory}

In the late 1950s, Frederick Herzberg (considered by many to be a pioneer in motivation theory) interviewed a group of employees to find out what made them satisfied and dissatisfied on the job. From these interviews, Herzberg went on to develop his theory that there are two dimensions to job satisfaction: "motivation" and "hygiene". Based on research investigating the relationship between motivation and job-satisfaction, Herzberg concluded that all variables that make people feel either good or bad about their jobs can be grouped into one of two categories, hence, his theory being known as the two-factor theory of motivation (Robbins, 1998; Spector, 2000; Swanepoel et al 1998). According to Amanda Werner in Nel, Gerber, Van Dyk, Haasbroek, Schultz, Sono, \& Werner (2003), hygiene factors are job context related and do not motivate, but prevent dissatisfaction when met adequately. Ten hygiene factors frequently identified are as follows (Herzberg, 1968 cited in Nel, et. al 2003; Oosthuizen, 2001) Robbins, 1998; Swanepoel, et. al 1998; 2003): Salary, Supervision, Relationship with supervisor, Relationship with colleagues, Company, Physical working conditions, Personal, Status and Job security. Only motivators can promote high performance. Six important motivators identified (Herzberg, 1968 cited in Nel, et. al 2003; Oosthuizen, 2001; Robbins, 1998; Swanepoel et. al 1998; 2003) are Achievement, Recognition, Responsibility Advancement, The work itself. Job enrichment is one technique aimed at incorporating motivators into a job (Nel, et. al 2003). 


\subsubsection{Alderfer's ERG Theory}

Alderfer's Existence, Relatedness, Growth theory (ERG Theory) is similar to Maslow's theory in that it is also based on the fulfilment of needs (Oosthuizen, 2001; Spector, 2000). However, his theory is based on the fulfilment of three basic needs as opposed to the five levels of basic needs identified by Maslow (Greenberg \& Baron, 2003; Spector, 2000). According to Greenberg and Baron (2003); Robbins, (1998) and Spector (2000), the three needs specified by ERG theory are: Existence needs, Relatedness needs and Growth needs.

\section{Research Methodology}

According to Leedy (2001:67) a methodology is an operational framework within which facts are placed so that meaning is seen more clearly. It describes how something will be done. It is a set of analytical methods, procedures and techniques used to collect and analyse information appropriate for evaluation of a particular project or activity.

\section{Population and Sample of the Study}

The target population was all employees and managers in a selected public service department in the Limpopo Province. The total number of the population was seventy one (71).

\section{Sample Size and Sampling Procedure}

A non-probability sampling procedure was used to select the sample. Specifically, a convenience sampling technique was applied. The rationale for using a non-probability sampling is that, it is much less complicated, much less expensive and it can be done on a spur of the moment basis to take advantage of available and perhaps unanticipated respondents without the statistical complexity of a probability sample. Convenience sampling is also known as accidental sampling. It takes people that are easily available for example, those at the scene. The study conducted the research at different times of the day and week in order to reduce biasness. Convenience sampling also results in great savings in time and money and this is a great advantage considering the issue of finances (Bailey, 2003:45).

\section{Research Design}

The research design that was used in this research is a quantitative approach. This was suitable because it was possible to rigorously test the collected data using scientific means, thus helping one to be sure of its liabilities. Furthermore, a quantitative approach allows for large quantities of data to be quantified and compared.

\section{Data collection}

According to Bailey (1994:119), the study can use closed ended questionnaires to obtain information from the respondents. A questionnaire can be defined as a set of questions designed to generated data necessary for sampling the objectives of the research project.

Proctor (2000:156) further states that a questionnaire is a data collection instrument which formally sets out the way in which research questions of interest should be asked. It is important for questions to be structured in proper wording to produce accurate information.

\section{Data Analysis}

Descriptive statistics was used to analyse data. This encompasses the use of bar graphs and tables to show the results in percentages. The study rearranged and sorted out the information collected. The information was then selected, differentiated and broken down into components related to each other the aim of data analysis is to check the testability of the research questions and hypothesis of the study. The objective is to test the validity of research questions in relation to the factors affecting the level of motivation of employees in a selected public service department in the Limpopo Province. 


\section{Research Findings}

The study was done on the levels of motivation among employees in a selected public service department in the Limpopo Province and as a result the following data was retrieved.

\subsection{Section A: Biological Information}

The study distributed 30 questionnaires but only 29 correctly filled questionnaires were returned.

\subsubsection{Age}

Six (20\%) were people under 35 years of age; 16 (53\%) were people between 35 and 45 years (20\%) were people between 46 and 55 years and 1 person was 56 years old making a percentage of $3.3 \%$.

\subsubsection{Gender}

The figure below shows that there were $7(23 \%)$ males and 22 (73\%) females.

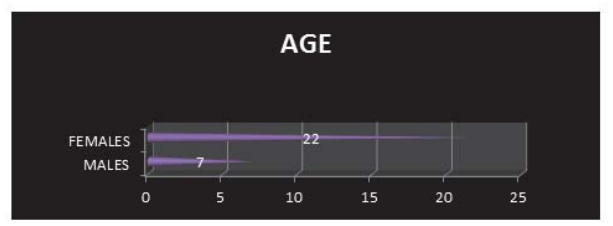

Figure 1: Age Distribution

\subsubsection{Race}

The figure shows that there were 28 (93\%) blacks and 1 (3.3\%) whites

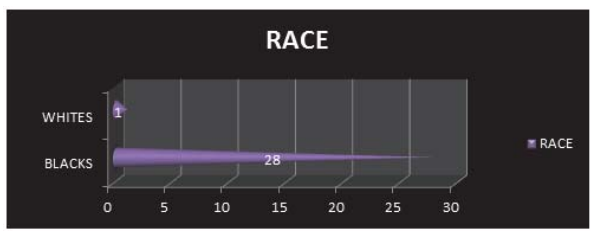

Figure 2: Race Distribution

\subsubsection{Work experience}

There were 11 (36.67\% who had 1 to 10 years' experience; 11 (36.67\%) had 10-20 years and 7 (23.3\%) had 20-30 years.

\subsubsection{Marital status}

There were 9 (30\%) married people; 16 (53.3\%); single people were 2 (6.67) divorced and 2 (6.67\%) widowed.

\subsubsection{Qualification}

There were 15 (50\%) people with matric; 9 (30\%) with diplomas; 2 (6.67\%) with degrees and others $3(10 \%)$. Others include people who left school at primary level, at high school level and those who never went to school. 


\subsection{Section B: Motivation}

\subsubsection{Working conditions}

The figure below indicates that $8(26.67 \%)$ strongly agree with the statement that my working conditions are satisfactory, $6(20 \%)$ agree, $1(3.3 \%)$ not sure, 5 (16.67\%) disagree and 9 (30\%) strongly disagree.

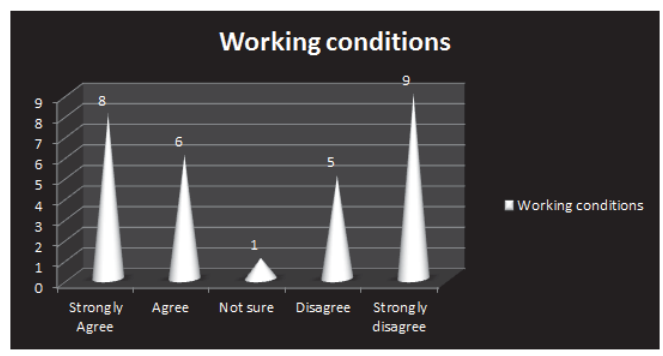

Figure 3: Working conditions

\subsubsection{Office environment}

The figure indicates that $6(20 \%)$ srongly agree with the statement that my office environment helps me to perform better and quality services; 8 (26.67\%) agree; 1 (3.3\%) not sure; 5 (16.67\%) disagree and 9 (30\%) strongly disagree.

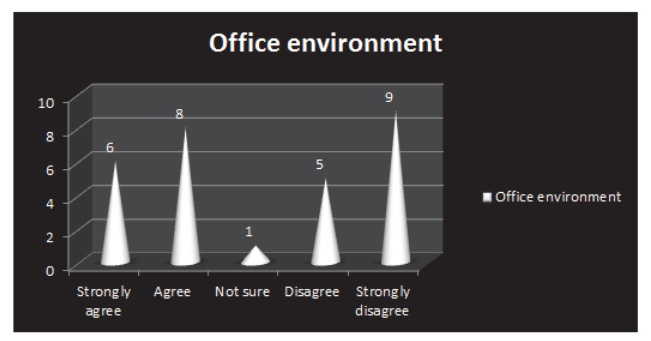

Figure 4: Office environment

\subsubsection{Training}

The table below indicates that $3(10 \%)$ strongly agree with the statement that necessary training is given in order for me to perform my duties better; 7 (23.3\%) agree; $4(13.3 \%)$ not sure; $4(13.3 \%)$ disagree and $9(30 \%)$ strongly disagree.

Table 1: training

\begin{tabular}{lcc} 
& Frequency & Percentage \\
Strongly agree & 3 & 10 \\
Agree & 7 & 23.3 \\
Not sure & 4 & 13.3 \\
Disagree & 4 & 13.3 \\
Strongly disagree & 9 & 30 \\
\hline
\end{tabular}

\subsubsection{Challenging and motivating factors}

The findings revealed that $6(20 \%)$ of the people strongly agreed with the statement that my work is challenging and 
motivating; 10 (66.67\%) agree; 4 (13.3\%) not sure and 9 (30\%) strongly disagree.

Table 2: Challenging and motivating factors

\begin{tabular}{lcc} 
& Frequency & Percentage \\
Strongly agree & 6 & 20 \\
Agree & 10 & 66.67 \\
Not sure & 4 & 13.3 \\
Disagree & 0 & 0 \\
Strongly disagree & 9 & 30 \\
\hline
\end{tabular}

\subsubsection{Decision making}

In terms of decision making the findings revealed that $2(6.67 \%)$ strongly agree with the statement that I partake in decision making in my department; 4 (13.3\%) agree; 2 (6.67\%) not sure; 6 (20\%) disagree and 15 (50\%) strongly disagree.

Table 3: decision making

\begin{tabular}{lcc} 
& Frequency & Percentage \\
\cline { 2 - 3 } Strongly agree & 2 & 6.67 \\
Agree & 4 & 13.3 \\
Not sure & 2 & 6.67 \\
Disagree & 6 & 20 \\
Strongly disagree & 15 & 50 \\
\hline
\end{tabular}

\subsubsection{Vision and mission}

The study findings revealed that (16.7\%) strongly agree with the statement that I am inspired by the vision and mission of my department; 7(23.3\%) not sure; 1 (3.3\%) disagree and 9 (30\%) strongly disagree.

\subsubsection{Feedback}

The study findings revealed that three (10\%) strongly agree with the statement that feedback on my performance is given timorously; 3 (10\%) agree; 6(20\%) not sure; 2 (6.67\%) disagree and 2 (6.67\%) strongly agree.

\subsubsection{Placement}

The study findings revealed that $5(16.67 \%)$ strongly agree with the statement that I am correctly placed in my department; 8 (26.67\%) agree; 9 (30\%) not sure; 1 (3.3\%) disagree and 8(26.67\%) strongly disagree.

\subsubsection{Pride}

The study findings revealed that $4(13.3 \%)$ strongly agree with the statement that I am proud of working in this department; 8 (26.67\%) agree; 8 (26.67\%) not sure; 1 (3.3\%) disagree and 8 (26.67\%) strongly disagree.

\subsubsection{Politics}

The study findings revealed that $8(26.67 \%)$ strongly agree with the statement that policies allow me to render quality services to my customers; 9 (26.67\%) agree; 6 (20\%) not sure 2 (6.67\%) disagree and 5 (16.67\%) strongly disagree. 


\subsection{Section C: Management and motivation}

\subsubsection{Helpful and understandings}

The study findings revealed that $8(26.67 \%)$ strongly agree with the statement that my supervisor is helpful and understanding; 5 (16.67\%) agree; 8 (26.67\%) not sure; 2 (6.67\%) disagree and $6(20 \%)$ strongly agree.

\subsubsection{Work related problems}

The study findings revealed that $5(16.67 \%)$ strongly agree with the statement that the management addresses work related problems; 4 (13.3\%) agree; 3 (10\%) not sure; 7 (23.3\%) disagree and 10 (66.67\%) strongly agree.

\subsubsection{Skills}

The study findings revealed that $8(26.67 \%)$ strongly agree with the statement that my supervisor encourages me to develop my skills; 6(20\%) agree; 2(6.67\%) not sure; 3(10\%) disagree and 10(66.67\%) strongly disagree.

Table 4: Skills

\begin{tabular}{lcc} 
& Frequency & Percentage \\
Strongly agree & 8 & 26.67 \\
Agree & 6 & 20 \\
Not sure & 2 & 6.67 \\
Disagree & 3 & 10 \\
Strongly disagree & 10 & 66.67 \\
\hline
\end{tabular}

\subsubsection{Interpersonal relations}

The study findings revealed that $7(23.3 \%)$ strongly agree with the statement that my supervisor has good interpersonal relations; 5(16.67\%) agree; 5(16.67\%) not sure; 5 (16.67\%) disagree and 7(23.3\%) strongly disagree.

\subsubsection{Recognition}

The study findings revealed that $6(20 \%)$ strongly agree with the statement that I get recognized for good performance; 5(16.67\%) agree; 2 (6.67\%) not sure; 4 (13.3\%) disagree and 12(40\%) strongly disagree.

\subsubsection{Employee needs}

The study findings revealed that $3(10 \%)$ strongly agree with the statement that the management is sensitive to employee needs; 3(10\%) agree; 9(30\%) not sure; 5 (16.67\%) disagree and 9 (30\%) strongly disagree.

\subsubsection{Grievances}

The study findings revealed that $6(20 \%)$ strongly agree with the statement that my supervisor addresses my grievances; 2(6.67\%) agree; 6(20\%) not sure; 4(13.3\%) disagree and 11 (36.67\%) strongly disagree.

\subsubsection{Access to telephone, fax, computer and transport facilities}

The study findings revealed that $2(6.67 \%)$ strongly agree with the statement that I have the necessary access to telephone, fax, computer and transport facilities to render services efficiently; $3(10 \%)$ agree; 4(13.3\%) not sure; $8(26.6 \%)$ disagree and $12(40 \%)$ strongly disagree. 


\subsubsection{Access to information}

The study findings revealed that $4(13.3 \%)$ strongly agree with the statement that I have access to every information in my department; 5 (16.67\%) agree; $9(30 \%)$ not sure; 5(16.67\%) disagree and 6(20\%) strongly disagree.

\subsubsection{Team working spirit}

The study findings revealed that $6(20 \%)$ strongly agree with the statement that my supervisor encourages team working spirit; 6(20\%) agree; 4(13.3\%) not sure; 2(6.67\%) disagree and 11(36.67\%) strongly disagree.

\subsubsection{Open door policy}

The study findings revealed that 4(13.3\%) strongly agree with the statement that management has an open door policy; $4(13.3 \%$ agree; $4(13.3 \%)$ not sure; $3(10 \%)$ disagree and $14(46.67 \%)$ strongly disagree.

\section{Discussion}

A few of the respondents also displayed some sensitivity in disclosing their names on their questionnaires. After consulting the study, they opted to only sign the questionnaire or to remain anonymous.

The results showed that the motivation factor and management and motivation factor had an alpha above 0.90 . The minimum acceptable level is said to be 0.80 . Therefore, it can be deduced that the factors had high internal consistency reliability

- What are the levels of motivation of public service employees in a selected public service department in the Limpopo Province?

Eighty one percent of the respondents claimed to be Not Satisfied with their Pay hence low levels of motivation. However, this is still significantly lower than that reported by the South African public service industry that showed $84 \%$ of the respondents were Not Satisfied. It also contrasts findings by Carrell, Elbert, Hatfield, Grobler, Marx \& van der Schyf (1999:561) that reported pay as often being the lowest-ranked factor on job satisfaction Surveys.

- What are the factors that affect the levels of employees' level of motivation in a selected public service department in the Limpopo Province?

It is clear that most of the respondents are to some degree Satisfied with the Work Itself (98\%). On average the respondents were Satisfied with Work Itself (mean $=3.20$ ). This result correlates with the Job Characteristics Model suggesting that the respondents are Satisfied with their work content. Overall job satisfaction should be high since Work Itself is considered a motivator and a major source of satisfaction as highlighted in Herzberg's model. In South Africa, a study was done to determine the relative importance of motivating factors in the public service industry using Herzberg's model and the highest ranked factor was the job itself (Mould, 2004).

- What are the factors that positively affect the employees' level of motivation in a selected public service department in the Limpopo Province?

On the issue of overall Working Conditions ( which included the office environment, training, challenging and motivating factors, decision making, vision and mission, feedback, placement, pride factor and politics) $82 \%$ were Satisfied. While it is necessary for comfort and to facilitate work, working conditions is a hygiene factor according to Herzberg, thus it prevents dissatisfaction but does not lead to satisfaction. Therefore, it is expected that this would not influence the overall job satisfaction.

- What strategies does the management use in order to rectify the problem of employees' levels of motivation? The management of this public service department uses the Performance Management System (PMS) but lack the necessary training to properly run this programme.

\section{Conclusions and Recommendations}

In conclusion, the factors that affect the levels of motivation among employees vary, job satisfaction and involvement are the most important factors, employees in the public service department are demotivated and demoralized and lastly, 
management is lacking in motivation skills. The majority of employees at the public service department are not satisfied with the working conditions and they view their work as not challenging thus as such their level of motivation is very low.

The following recommendations should be followed; the public service department should ensure that training programmes are implemented as stipulated in its policy. For example, managers need to be trained in Performance Management System (PMS) in order to know how to make employees perform as expected. Employee skills and needs should be identified in order to make proper placement and provide proper training. In order to attract and retain capacitated employees. The public service department should improve working conditions and emphasise job satisfaction and involvement. It is imperative for employees, through their trade unions to be involved in decision making.

\section{References}

Carrell, M.R., Elbert, F.E., Hatfield, R.D., Grobler, P.A., Marx, M. and van der Schyf, S. 1999. Human Resource Management in South Africa. Cape Town: Pearson Education South Africa.

Greenberg, J. \& Baron, R.A. 2003. Behavior in Organisations. New Jersey: Pearson Education, Inc.

Leedy, P.D. (2001). Practical research planning and design, 7th Edition. Macmillan, New York.

Luthans, Fred. Organizational Behavior. - McGraw-Hill Book Company, 1989. - 637 p. - ISBN 0-07- 039161-0.

Mould, C. 2004. Factors Influencing the Motivation of Information Technology Professionals in the Workplace. [Online]. Available from http://www.fti.co.za/index.php?id=7\&news_id=9. [Accessed 2 January 2014].

Muchinsky, P. M. (2003). Psychology Applied to Work (7th Ed.). Belmont: Wadsworth/Thomson Learning.

Oosthuizen, T.F.J., (2001). Motivation influencing worker performance in a technical division of Telkom SA. Acta Commercii, Vol. 1, 1920.

Robbins, S.P. (1998). Organisational behaviour (8th ed.). New Jersey: Prentice Hall.

Nel, P.S, Gerber, P.D, Van Dyk, P.S, Haasbroek, G.D, Schultz, H.B, Sono, T \& Werner, A (Eds.), (2003) Human Resource Management (5th ed., pp. 434-464).

Mullins, L. (1996). Management and organization. 4th ed. London: Pitman.

Newstrom, W.J (2002). Organisational Behaviour at Work (7th Edition) Arizona State. University Publishers

Newstrom, John W Davis, Keith 8th ed. 1989. Organizational behavior: Human behavior at work McGraw-Hill Companies (Boston, Mass.)

Robbins,S.P, Odendaal, A. \& Roodt, G (2003). Consumer Behaviour (5 th Edition). Engelwood Cliffs. New Jersey. Prentice-Hall International Inc.

Schulze, S., \& Steyn, T., (2003). Educator's motivation: differences related to gender, age and experience. Acta Academia, 35(3), 138160.

Schiffman, L.G. \& Kanak, L.L. 2006. Consumer Behavior. 8th ed. United States of America: Pearson Edmotion Publishers.

Sherman A., Bohlander G., Snell S. Managing Human Resources. - Cinncinatti (Ohio): South-Western College Publishing, 1996/ - 10th edition.

Steyn, G.M. (2002). A theoretical analysis of educator motivation and morale. Educare, 31(1 \& 2), 82-101.

Spector, P.E. (2000). Organisational Psychology: Research and practice. New York: John Wiley \& Sons.

Swanepoel, B.J., Erasmus, B.J, Van Wyk M.N \& Schenk, H.W. 1998. South African Human Resource Management. Theory and practice. Cape Town: Zebra.

Swanepoel, B.J., Erasmus, B.J, Van Wyk M.N \& Schenk, H.W. 1998. South African Human Resource Management. Theory and practice (4th Ed). Cape Town: Zebra.

Van der Merwe, S \& Bisschoff, C (2001). General Management Study Guide: Telematic Learning Systems. Potchefstroom University for Christian Higher Education. 